\title{
Hydrophobic Polymer-Supported Catalyst for Organic Reactions in Water: Acid-Catalyzed Hydrolysis of Thioesters and Transprotection of Thiols
}

\author{
Shinya Iimura, Kei Manabe, and Shū Kobayashi* \\ Graduate School of Pharmaceutical Sciences, The University of Tokyo, Hongo, \\ Bunkyo-ku, Tokyo 113-0033, Japan
}

\section{Supporting Information}

\section{Experimental Section}

\section{General}

NMR spectra were recorded on a JEOL JNM-LA300 or JNM-LA400 spectrometer. Tetramethylsilane $(\delta=0)$ was used as an internal standard for ${ }^{1} \mathrm{H} \mathrm{NMR}$ and $\mathrm{CDCl}_{3}(\delta=$ 77.0) for ${ }^{13} \mathrm{C}$ NMR. High-performance liquid chromatography was carried out using following apparatuses; SHIMADZU LC-10AT (liquid chromatography), SHIMADZU SPD-10A (UV detector), and SHIMADZU CR8A Chromatopac. Column chromatography was conducted on Silica gel 60 (Merck) and preparative thin-layer chromatography (TLC) was carried out using Wakogel B-5F. All compounds were confirmed by comparison with commercially available compounds or published data.

\section{Preparation of polymer-supported sulfonic acid $\left(\mathrm{PS}_{-} \mathrm{SO}_{3} \mathrm{H}\right)$.}

To a suspension of polystyrene (10.06 g, 1\% DVB cross-linked, 200-400 mesh) in dichloromethane $(150 \mathrm{~mL})$ was slowly added a solution of chlorosulfonic acid $(0.37 \mathrm{~mL})$ in dichloromethane $(20 \mathrm{~mL})$ at $0{ }^{\circ} \mathrm{C}$, and the whole was shaken for $6 \mathrm{~h}$. THF/water $(5 / 1$, 
$60 \mathrm{~mL}$ ) was added, and after shaken at $\mathrm{rt}$ for $1 \mathrm{~h}$ and left overnight, the resin was collected on a glass filter, rinsed with water, water/THF, THF, and dichloromethane, and dried in vacuo to give the polymer-supported sulfonic acid $\left(\mathrm{PS}_{-} \mathrm{SO}_{3} \mathrm{H}\right)$. From a result of elemental analysis (found: $\mathrm{S}, 1.48 \%$ ), the sulfonic acid content was estimated as $0.462 \mathrm{mmol} / \mathrm{g}$.

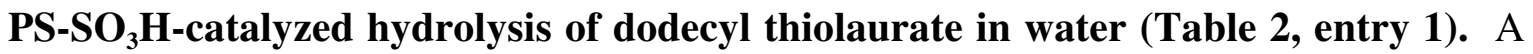
mixture of dodecyl thiolaurate $(96.3 \mathrm{mg}, 0.25 \mathrm{mmol})$ and the polymer-supported catalyst (PS-SO $\left.{ }_{3} \mathrm{H}, 54.5 \mathrm{mg}, 0.025 \mathrm{mmol}\right)$ in degassed water $(1.5 \mathrm{~mL})$ was stirred for $72 \mathrm{~h}$ under reflux conditions. The polymer was filtered and washed with water and dichloromethane after cooled to rt. The organic layer was dried over $\mathrm{Na}_{2} \mathrm{SO}_{4}$, and evaporated. The mixture was purified by flash column chromatography $\left(10 \mathrm{~g} \mathrm{SiO}_{2}\right)$ to give dodecanethiol (48.2 $\mathrm{mg}$, $95 \%$ ) containing the disulfide (2\%) from hexane eluate and lauric acid (47.8 $\mathrm{mg}, 95 \%)$ from AcOEt eluate. Dodecanethiol: ${ }^{1} \mathrm{H}$ NMR $\left(\mathrm{CDCl}_{3}\right) \delta 0.88(3 \mathrm{H}, \mathrm{t}, J=6.7 \mathrm{~Hz})$, 1.26-1.40 (19H, m), $1.61(2 \mathrm{H}, \mathrm{q}, J=7.4 \mathrm{~Hz}), 2.52(2 \mathrm{H}, \mathrm{q}, J=7.3 \mathrm{~Hz}) ;{ }^{13} \mathrm{C} \mathrm{NMR}\left(\mathrm{CDCl}_{3}\right)$ $\delta 14.13,22.71,24.68,28.41,29.11,29.37,29.55,29.62,29.65,29.67,31.94,34.08$. Lauric acid: ${ }^{1} \mathrm{H}$ NMR $\left(\mathrm{CDCl}_{3}\right) \delta 0.88(3 \mathrm{H}, \mathrm{t}, J=6.7 \mathrm{~Hz}), 1.23-1.40(16 \mathrm{H}, \mathrm{m}), 1.58-1.66$ $(2 \mathrm{H}, \mathrm{m}), 2.35(2 \mathrm{H}, \mathrm{t}, J=7.5 \mathrm{~Hz}) ;{ }^{13} \mathrm{C} \mathrm{NMR}\left(\mathrm{CDCl}_{3}\right) \delta 14.13,22.72,24.72,29.10,29.28$, $29.37,29.47,29.63,31.95,34.12,180.15$.

$\mathrm{PS}_{-} \mathrm{SO}_{3} \mathrm{H}$-catalyzed hydrolysis of ethyl thiolaurate in water (Table 2, entry 2). A mixture of ethyl thiolaurate $(61.3 \mathrm{mg}, 0.25 \mathrm{mmol})$ and the polymer-supported catalyst (PS$\left.\mathrm{SO}_{3} \mathrm{H}, 54.4 \mathrm{mg}, 0.025 \mathrm{mmol}\right)$ in degassed water $(1.5 \mathrm{~mL})$ was stirred for $36 \mathrm{~h}$ under reflux conditions. The polymer was filtered and washed with water and dichloromethane after cooled to rt. The organic layer was dried over $\mathrm{Na}_{2} \mathrm{SO}_{4}$, and evaporated. The mixture was purified by flash column chromatography $\left(5 \mathrm{~g} \mathrm{SiO}_{2}\right)$ to give lauric acid $(46.5 \mathrm{mg}, 93 \%)$ 
from AcOEt eluate. ${ }^{1} \mathrm{H}$ and ${ }^{13} \mathrm{C}$ NMR spectra were identical with those shown in the experimental procedure for Table 2, entry 1.

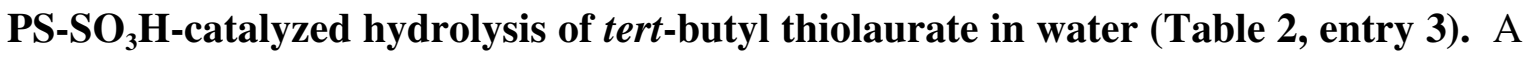
mixture of tert-butyl thiolaurate $(68.2 \mathrm{mg}, 0.25 \mathrm{mmol})$ and the polymer-supported catalyst (PS-SO $\left.{ }_{3} \mathrm{H}, 54.5 \mathrm{mg}, 0.025 \mathrm{mmol}\right)$ in degassed water $(1.5 \mathrm{~mL})$ was stirred for $168 \mathrm{~h}$ under reflux conditions. The polymer was filtered and washed with water and dichloromethane after cooled to rt. The organic layer was dried over $\mathrm{Na}_{2} \mathrm{SO}_{4}$, and evaporated. The mixture was purified by flash column chromatography $\left(2 \mathrm{~g} \mathrm{SiO}_{2}\right)$ to give lauric acid $(50.1 \mathrm{mg}$, quant.) from AcOEt eluate. ${ }^{1} \mathrm{H}$ and ${ }^{13} \mathrm{C}$ NMR spectra were identical with those shown in the experimental procedure for Table 2 , entry 1 .

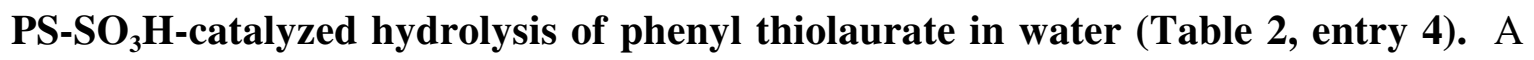
mixture of phenyl thiolaurate $(73.1 \mathrm{mg}, 0.25 \mathrm{mmol})$ and the polymer-supported catalyst $\left(\mathrm{PS}-\mathrm{SO}_{3} \mathrm{H}, 54.6 \mathrm{mg}, 0.025 \mathrm{mmol}\right)$ in degassed water $(1.5 \mathrm{~mL})$ was stirred for $24 \mathrm{~h}$ under reflux conditions. The polymer was filtered and washed with water and dichloromethane after cooled to rt. The organic layer was dried over $\mathrm{Na}_{2} \mathrm{SO}_{4}$, and evaporated. The mixture was purified by preparative TLC on silica gel to give lauric acid $(48.9 \mathrm{mg}, 98 \%) .{ }^{1} \mathrm{H}$ and ${ }^{13} \mathrm{C}$ NMR spectra were identical with those shown in the experimental procedure for Table 2 , entry 1.

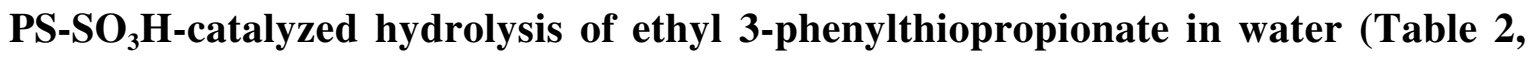
entry 5). A mixture of ethyl 3-phenylthiopropionate $(48.6 \mathrm{mg}, 0.25 \mathrm{mmol})$ and the polymer-supported catalyst $\left(\mathrm{PS}-\mathrm{SO}_{3} \mathrm{H}, 54.1 \mathrm{mg}, 0.025 \mathrm{mmol}\right)$ in degassed water $(1.5 \mathrm{~mL})$ was stirred for $24 \mathrm{~h}$ under reflux conditions. The polymer was filtered and washed with 
water and dichloromethane after cooled to rt. The organic layer was dried over $\mathrm{Na}_{2} \mathrm{SO}_{4}$, and evaporated. The mixture was purified by preparative TLC on silica gel to give hydrocinnamic acid $(31.8 \mathrm{mg}, 85 \%) .{ }^{1} \mathrm{H} \mathrm{NMR}\left(\mathrm{CDCl}_{3}\right) \delta 2.66-2.71(2 \mathrm{H}, \mathrm{m}), 2.89-2.99$ $(2 \mathrm{H}, \mathrm{m}), 7.17-7.32(5 \mathrm{H}, \mathrm{m}) ;{ }^{13} \mathrm{C} \mathrm{NMR}\left(\mathrm{CDCl}_{3}\right) \delta 30.56,35.61,126.38,128.32,128.56$, $140.13,179.25$.

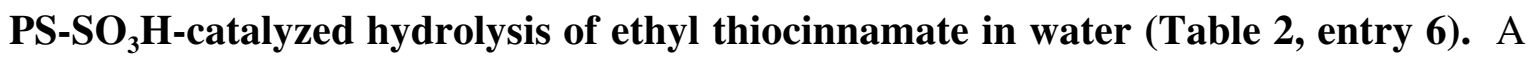
mixture of ethyl thiocinnamate $(48.2 \mathrm{mg}, 0.25 \mathrm{mmol})$ and the polymer-supported catalyst (PS-SO $\left.{ }_{3} \mathrm{H}, 54.3 \mathrm{mg}, 0.025 \mathrm{mmol}\right)$ in degassed water $(1.5 \mathrm{~mL})$ was stirred for $168 \mathrm{~h}$ under reflux conditions. The polymer was filtered and washed with water and dichloromethane after cooled to rt. The organic layer was dried over $\mathrm{Na}_{2} \mathrm{SO}_{4}$, and evaporated. The mixture was purified by preparative TLC on silica gel to give cinnamic acid $(33.3 \mathrm{mg}, 90 \%) .{ }^{1} \mathrm{H}$ $\operatorname{NMR}\left(\mathrm{CDCl}_{3}\right) \delta 6.46(1 \mathrm{H}, \mathrm{dd}, J=16.0,0.6 \mathrm{~Hz}), 7.39-7.42(3 \mathrm{H}, \mathrm{m}), 7.53-7.58(2 \mathrm{H}, \mathrm{m})$, $7.80(2 \mathrm{H}, \mathrm{d}, J=16.0 \mathrm{~Hz})$.

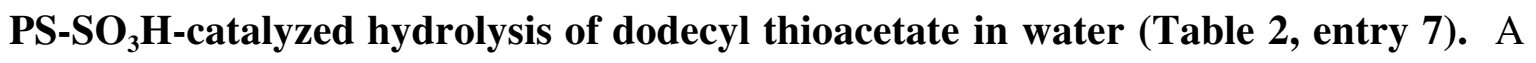
mixture of dodecyl thioacetate $(62.0 \mathrm{mg}, 0.25 \mathrm{mmol})$ and the polymer-supported catalyst (PS-SO $\left.{ }_{3} \mathrm{H}, 54.3 \mathrm{mg}, 0.025 \mathrm{mmol}\right)$ in degassed water $(1.5 \mathrm{~mL})$ was stirred for $24 \mathrm{~h}$ under reflux conditions. The reaction mixture was quenched with saturated aq. $\mathrm{NaHCO}_{3}$ after cooled to rt. The polymer was filtered and washed with water and ethyl acetate. The organic layer was dried over $\mathrm{Na}_{2} \mathrm{SO}_{4}$, and evaporated. Dodecanethiol (51.4 mg, quant.) was obtained as essentially pure form. ${ }^{1} \mathrm{H}$ and ${ }^{13} \mathrm{C}$ NMR spectra were identical with those shown in the experimental procedure for Table 2, entry 1. 
Reaction using 2 mol\% PS-SO 3 H (Table 2, entry 7). A mixture of dodecyl thioacetate $(61.3 \mathrm{mg}, 0.25 \mathrm{mmol})$ and the polymer-supported catalyst $\left(\mathrm{PS}-\mathrm{SO}_{3} \mathrm{H}, 10.8 \mathrm{mg}, 0.005\right.$ $\mathrm{mmol})$ in degassed water $(1.5 \mathrm{~mL})$ was stirred for $48 \mathrm{~h}$ under reflux conditions. The polymer was filtered and washed with water and dichloromethane after cooled to rt. The organic layer was dried over $\mathrm{Na}_{2} \mathrm{SO}_{4}$, and evaporated. Dodecanethiol (51.1 mg, quant.) was obtained as essentially pure form. ${ }^{1} \mathrm{H}$ and ${ }^{13} \mathrm{C}$ NMR spectra were identical with those shown in the experimental procedure for Table 2, entry 1.

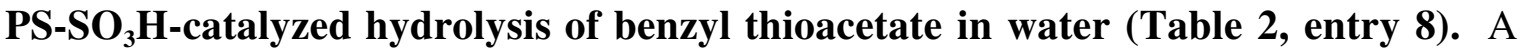
mixture of benzyl thioacetate $(42.2 \mathrm{mg}, 0.25 \mathrm{mmol})$ and the polymer-supported catalyst (PS-SO $\left.{ }_{3} \mathrm{H}, 54.5 \mathrm{mg}, 0.025 \mathrm{mmol}\right)$ in degassed water $(1.5 \mathrm{~mL})$ was stirred for $24 \mathrm{~h}$ under reflux conditions. The reaction mixture was quenched with saturated aq. $\mathrm{NaHCO}_{3}$ after cooled to rt. The polymer was filtered and washed with water and ethyl acetate. The organic layer was dried over $\mathrm{Na}_{2} \mathrm{SO}_{4}$, and evaporated. Benzyl mercaptan $(24.8 \mathrm{mg}, 80 \%)$ was obtained as essentially pure form. ${ }^{1} \mathrm{H} \mathrm{NMR}\left(\mathrm{CDCl}_{3}\right) \delta 1.76(1 \mathrm{H}, \mathrm{t}, J=7.5 \mathrm{~Hz}), 3.74$ $(2 \mathrm{H}, \mathrm{d}, J=7.7 \mathrm{~Hz}), 7.20-7.33(5 \mathrm{H}, \mathrm{m})$. The yield was $80 \%$ because of the volatility of the product.

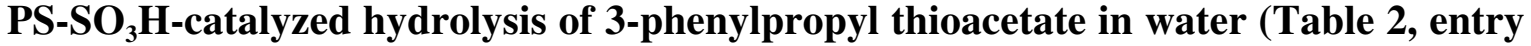

9). A mixture of 3-phenylpropyl thioacetate $(48.3 \mathrm{mg}, 0.25 \mathrm{mmol})$ and the polymersupported catalyst (PS-SO $\left.\mathrm{S}_{3} \mathrm{H}, 54.2 \mathrm{mg}, 0.025 \mathrm{mmol}\right)$ in degassed water $(1.5 \mathrm{~mL})$ was stirred for $24 \mathrm{~h}$ under reflux conditions. The polymer was filtered and washed with water and dichloromethane after cooled to rt. The organic layer was dried over $\mathrm{Na}_{2} \mathrm{SO}_{4}$, and evaporated. 3-Phenylpropane-1-thiol (40.0 mg, quant.) was obtained as essentially pure form. ${ }^{1} \mathrm{H} \mathrm{NMR}\left(\mathrm{CDCl}_{3}\right) \delta 1.35(1 \mathrm{H}, \mathrm{t}, J=7.8 \mathrm{~Hz}), 1.93(2 \mathrm{H}, \mathrm{q}, J=7.3 \mathrm{~Hz}), 2.53(2 \mathrm{H}, \mathrm{q}, J$ 
$=7.3 \mathrm{~Hz}), 2.72(2 \mathrm{H}, \mathrm{t}, J=7.5 \mathrm{~Hz}), 7.16-7.31(5 \mathrm{H}, \mathrm{m}) ;{ }^{13} \mathrm{C} \mathrm{NMR}\left(\mathrm{CDCl}_{3}\right) \delta 23.98,34.35$, $35.47,125.96,128.40,128.46,141.26$.

$\mathrm{PS}_{-} \mathrm{SO}_{3} \mathrm{H}$-catalyzed hydrolysis of dodecyl thiobenzoate in water (Table 2, entry 10). A mixture of dodecyl thiobenzoate $(76.6 \mathrm{mg}, 0.25 \mathrm{mmol})$ and the polymer-supported catalyst (PS-SO $\left.{ }_{3} \mathrm{H}, 108.2 \mathrm{mg}, 0.050 \mathrm{mmol}\right)$ in degassed water $(1.5 \mathrm{~mL})$ was stirred for 168 $\mathrm{h}$ under reflux conditions. The polymer was filtered and washed with water and dichloromethane after cooled to rt. The organic layer was dried over $\mathrm{Na}_{2} \mathrm{SO}_{4}$, and evaporated. The mixture was purified by flash column chromatography $\left(5 \mathrm{~g} \mathrm{SiO}_{2}\right)$ to give dodecanethiol (45.3 mg, 89\%) containing the disulfide (5\%) from hexane eluate. ${ }^{1} \mathrm{H}$ and ${ }^{13} \mathrm{C}$ NMR spectra were identical with those shown in the experimental procedure for Table 2 , entry 1.

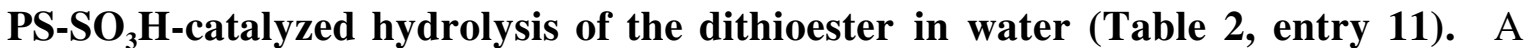
mixture of the dithioester $(63.8 \mathrm{mg}, 0.25 \mathrm{mmol})$ and the polymer-supported catalyst (PS$\left.\mathrm{SO}_{3} \mathrm{H}, 54.1 \mathrm{mg}, 0.025 \mathrm{mmol}\right)$ in degassed water $(1.5 \mathrm{~mL})$ was stirred for $24 \mathrm{~h}$ under reflux conditions. The polymer was filtered and washed with water and dichloromethane after cooled to rt. The organic layer was dried over $\mathrm{Na}_{2} \mathrm{SO}_{4}$, and evaporated. 1,2Benzenedimethanethiol ${ }^{1}(42.1 \mathrm{mg}, 99 \%)$ was obtained as essentially pure form. ${ }^{1} \mathrm{H}$ NMR $\left(\mathrm{CDCl}_{3}\right) \delta 1.85(2 \mathrm{H}, \mathrm{t}, J=7.2 \mathrm{~Hz}), 3.85(4 \mathrm{H}, \mathrm{d}, J=7.2 \mathrm{~Hz}), 7.17-7.29(4 \mathrm{H}, \mathrm{m}) ;{ }^{13} \mathrm{C} \mathrm{NMR}$ $\left(\mathrm{CDCl}_{3}\right) \delta 26.06,127.90,129.72,138.68$.

Recycle experiment of PS-SO $\mathbf{H}_{3} \mathrm{H}$ (Eq. 1). A mixture of dodecyl thioacetate (245.2 mg, $1.0 \mathrm{mmol})$ and the polymer-supported catalyst $\left(\mathrm{PS}-\mathrm{SO}_{3} \mathrm{H}, 216.7 \mathrm{mg}, 0.10 \mathrm{mmol}\right)$ in degassed water $(6 \mathrm{~mL})$ was stirred for $24 \mathrm{~h}$ under reflux conditions. The polymer was 
filtered through a glass filter after the reaction mixture was cooled to $\mathrm{rt}$, and the polymer was washed with water and ether. The organic layer was dried over $\mathrm{Na}_{2} \mathrm{SO}_{4}$, and evaporated. Dodecanethiol (204 mg, quant.) was obtained as essentially pure form. ${ }^{1} \mathrm{H}$ and ${ }^{13} \mathrm{C}$ NMR spectra were identical with those shown in the experimental procedure for Table 2, entry 1. The recovered $\mathrm{PS}-\mathrm{SO}_{3} \mathrm{H}$ was reused several times without loss of activity after dried under vacuum.

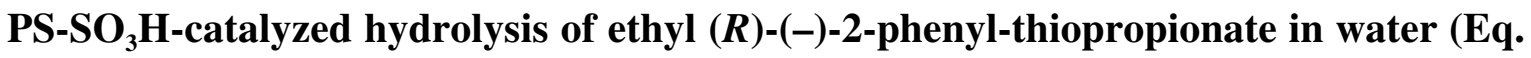
2). A mixture of ethyl (R)-(-)-2-phenyl-thiopropionate $(48.5 \mathrm{mg}, 0.25 \mathrm{mmol})$ and the polymer-supported catalyst $\left(\mathrm{PS}-\mathrm{SO}_{3} \mathrm{H}, 54.5 \mathrm{mg}, 0.025 \mathrm{mmol}\right)$ in degassed water $(1.5 \mathrm{~mL})$ was stirred for $72 \mathrm{~h}$ under reflux conditions. The polymer was filtered and washed with water and dichloromethane after cooled to rt. The organic layer was dried over $\mathrm{Na}_{2} \mathrm{SO}_{4}$, and evaporated. The mixture was purified by preparative TLC on silica gel to give $(R)$ (-)-2-phenylpropionic acid (27.8 $\mathrm{mg}, 74 \%) .{ }^{1} \mathrm{H} \mathrm{NMR}\left(\mathrm{CDCl}_{3}\right) \delta 1.51(3 \mathrm{H}, \mathrm{d}, J=7.1 \mathrm{~Hz})$, $3.73(1 \mathrm{H}, \mathrm{q}, J=7.1 \mathrm{~Hz}), 7.23-7.36(5 \mathrm{H}, \mathrm{m}) ;{ }^{13} \mathrm{C} \mathrm{NMR}\left(\mathrm{CDCl}_{3}\right) \delta 18.10,45.35,127.40$, $127.60,128.69,139.76,180.69$. The enantiomeric excess of the product was determined by HPLC analysis (93\% ee. Daicel Chiralcel OD, hexane/i-PrOH/ $\mathrm{HCO}_{2} \mathrm{H}=98 / 2 / 1$ ).

$\mathrm{PS}_{-} \mathrm{SO}_{3} \mathrm{H}$-catalyzed transprotection of dodecanethiol in water (Table 3, entry 1). A mixture of dodecyl thioacetate $(122.8 \mathrm{mg}, 0.50 \mathrm{mmol})$, triphenylmethanol (130.6 mg, 0.50 $\mathrm{mmol})$, and the polymer-supported catalyst $\left(\mathrm{PS}-\mathrm{SO}_{3} \mathrm{H}, 108.5 \mathrm{mg}, 0.050 \mathrm{mmol}\right)$ in degassed water $(3.0 \mathrm{~mL})$ was stirred for $48 \mathrm{~h}$ under reflux conditions. The reaction mixture was quenched with saturated aq. $\mathrm{NaHCO}_{3}$ and brine after cooled to rt. The polymer was filtered and washed with water and ethyl acetate. The organic layer was dried over $\mathrm{Na}_{2} \mathrm{SO}_{4}$, and evaporated. The mixture was purified by preparative TLC on silica gel to 
give dodecyl triphenylmethyl sulfide ${ }^{2}(202.8 \mathrm{mg}, 91 \%) .{ }^{1} \mathrm{H} \mathrm{NMR}\left(\mathrm{CDCl}_{3}\right) \delta 0.87(3 \mathrm{H}, \mathrm{t}, J$ = 6.7 Hz), 1.22-1.41 (20H, m), $2.13(2 \mathrm{H}, \mathrm{t}, J=7.3 \mathrm{~Hz}), 7.15-7.29(9 \mathrm{H}, \mathrm{m}), 7.39-7.43$ $(6 \mathrm{H}, \mathrm{m})$.

$\mathrm{PS}_{-\mathrm{SO}_{3} \mathrm{H}-c a t a l y z e d}$ transprotection of dodecanethiol in water (Table 3, entry 2). A mixture of dodecyl thioacetate $(61.3 \mathrm{mg}, 0.25 \mathrm{mmol})$, benzhydrol $(92.2 \mathrm{mg}, 0.50 \mathrm{mmol})$, and the polymer-supported catalyst $\left(\mathrm{PS}-\mathrm{SO}_{3} \mathrm{H}, 54.4 \mathrm{mg}, 0.025 \mathrm{mmol}\right.$ ) in degassed water (1.5 mL) was stirred for $48 \mathrm{~h}$ under reflux conditions. The reaction mixture was quenched with saturated aq. $\mathrm{NaHCO}_{3}$ and brine after cooled to rt. The polymer was filtered and washed with water and ethyl acetate. The organic layer was dried over $\mathrm{Na}_{2} \mathrm{SO}_{4}$, and evaporated. The mixture was purified by preparative TLC on silica gel to give benzhydryl dodecyl sulfide ${ }^{3}(82.8 \mathrm{mg}, 90 \%) .{ }^{1} \mathrm{H}$ NMR $\left(\mathrm{CDCl}_{3}\right) \delta 0.88(3 \mathrm{H}, \mathrm{t}, J=6.6 \mathrm{~Hz}), 1.23-1.35$ (18H, m), 1.49-1.61 (2H, m), $2.37(2 \mathrm{H}, \mathrm{t}, J=7.3 \mathrm{~Hz}), 5.14(1 \mathrm{H}, \mathrm{s}), 7.19-7.33(6 \mathrm{H}, \mathrm{m})$, 7.41-7.44 (4H, m).

$\mathrm{PS}_{-} \mathrm{SO}_{3} \mathrm{H}$-catalyzed transprotection of dodecanethiol in water (Table 3, entry 3). A mixture of dodecyl thioacetate $(61.7 \mathrm{mg}, 0.25 \mathrm{mmol})$, 4-methoxybenzyl alcohol (70.6 $\mathrm{mg}$, $0.51 \mathrm{mmol})$, and the polymer-supported catalyst $\left(\mathrm{PS}-\mathrm{SO}_{3} \mathrm{H}, 54.3 \mathrm{mg}, 0.025 \mathrm{mmol}\right)$ in degassed water $(1.5 \mathrm{~mL})$ was stirred for $48 \mathrm{~h}$ under reflux conditions. The reaction mixture was quenched with saturated aq. $\mathrm{NaHCO}_{3}$ and brine after cooled to rt. The polymer was filtered and washed with water and ethyl acetate. The organic layer was dried over $\mathrm{Na}_{2} \mathrm{SO}_{4}$, and evaporated. The mixture was purified by preparative TLC on silica gel to give dodecyl 4-methoxybenzyl sulfide ${ }^{3}$ (56.9 mg, 71\%). ${ }^{1} \mathrm{H}$ NMR $\left(\mathrm{CDCl}_{3}\right) \delta$ $0.88(3 \mathrm{H}, \mathrm{t}, 6.8 \mathrm{~Hz}), 1.24(18 \mathrm{H}, \mathrm{s}), 1.51-1.58(2 \mathrm{H}, \mathrm{m}), 2.39(2 \mathrm{H}, \mathrm{t}, J=7.4 \mathrm{~Hz}), 3.66(2 \mathrm{H}$, s), $3.82(3 \mathrm{H}, \mathrm{s}), 6.84(2 \mathrm{H}, \mathrm{d}, J=8.5 \mathrm{~Hz}), 7.22(2 \mathrm{H}, \mathrm{d}, J=8.5 \mathrm{~Hz})$. 
PS-SO 3 H-catalyzed transprotection of benzyl mercaptan in water (Table 3, entry 4). A mixture of benzyl thioacetate $(42.1 \mathrm{mg}, 0.25 \mathrm{mmol})$, triphenylmethanol $(65.4 \mathrm{mg}, 0.25$ $\mathrm{mmol}$ ) and the polymer-supported catalyst (PS-SO$\left.{ }_{3} \mathrm{H}, 54.0 \mathrm{mg}, 0.025 \mathrm{mmol}\right)$ in degassed water $(1.5 \mathrm{~mL})$ was stirred for $24 \mathrm{~h}$ under reflux conditions. The reaction mixture was quenched with saturated aq. $\mathrm{NaHCO}_{3}$ and brine after cooled to rt. The polymer was filtered and washed with water and ethyl acetate. The organic layer was dried over $\mathrm{Na}_{2} \mathrm{SO}_{4}$, and evaporated. The mixture was purified by preparative TLC on silica gel to give benzyl triphenylmethyl sulfide ${ }^{3}(80.4 \mathrm{mg}, 88 \%) .{ }^{1} \mathrm{H} \mathrm{NMR}\left(\mathrm{CDCl}_{3}\right) \delta 3.30(2 \mathrm{H}, \mathrm{s})$, 7.11-7.31 (14H, m), 7.45-7.49 (6H, m).

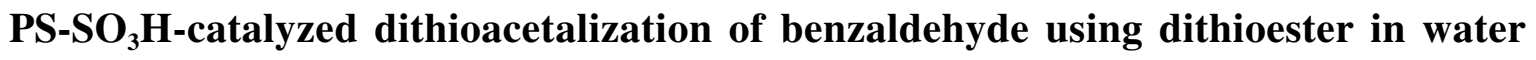

(Eq. 3). A mixture of benzaldehyde (26.7 mg, $0.25 \mathrm{mmol})$, the dithioester ( $53.0 \mathrm{mg}, 0.276$ $\mathrm{mmol}$ ) and the polymer-supported catalyst (PS-SO$\left.{ }_{3} \mathrm{H}, 54.2 \mathrm{mg}, 0.025 \mathrm{mmol}\right)$ in degassed water $(1.5 \mathrm{~mL})$ was stirred for $24 \mathrm{~h}$ under reflux conditions. The polymer was filtered and washed with water and dichloromethane after cooled to rt. The organic layer was dried over $\mathrm{Na}_{2} \mathrm{SO}_{4}$, and evaporated. The mixture was purified by preparative TLC on silica gel to give 2-phenyl-1,3-dithiane ${ }^{4}(48.0 \mathrm{mg}, 98 \%) .{ }^{1} \mathrm{H}$ NMR $\left(\mathrm{CDCl}_{3}\right) \delta 1.88-1.98(1 \mathrm{H}, \mathrm{m})$, 2.14-2.18 (1H, m), 2.87-2.93 (2H, m), 3.02-3.09 (2H, m), $5.17(1 \mathrm{H}, \mathrm{s}), 7.27-7.35(3 \mathrm{H}$, m), $7.47(2 \mathrm{H}, \mathrm{d}, J=7.3 \mathrm{~Hz}) ;{ }^{13} \mathrm{C} \mathrm{NMR}\left(\mathrm{CDCl}_{3}\right) \delta 25.11,32.09,51.48,127.75,128.43$, $128.72,139.11$.

\section{References}

(1) Patney, H. K. Synth. Commun. 1993, 23, 1829. 
(2) Tam-Chang, S.-W.; Mason. J. C. Tetrahedron 1999, 55, 13333.

(3) Manabe, K.; Iimura, S.; Sun, X.-M.; Kobayashi, S. J. Am. Chem. Soc. 2002, 124, 11971.

(4) Ku, B.; Oh, D. Y. Synth. Commun. 1989, 19, 433. 